\title{
Problems of the measurement management systems evaluation for business entities on voluntary basis
}

\author{
Chyzhyk Ivan ${ }^{1}$, Danylina Iryna ${ }^{2}$ \\ ${ }^{1,2} \mathrm{SE} \ll$ Ukrmetrteststandart», Ukraine \\ E-mail: ichizhyk@ukrcsm.kiev.ua
}

\begin{abstract}
Questions concerning evaluation and confirmation of measurement capabilities for business entities on a voluntary basis are considered.

Existing problems in executing this kind of activity by enterprises, which are regulated by the Ministry of Economy of Ukraine (metrological centers) as well as other enterprises and organizations are analyzed.

Causes of impossibility to issue certificates on compliance of the measurement management systems with requirements of DSTU ISO $10012^{[1]}$ as a result of providing the above-mentioned operations are determined.
\end{abstract}

Keywords: evaluation and confirmation of measurement capabilities, compliance of the measurement management systems capabilities, measurement uncertainty, traceability.

Abbreviation: MOD - modified compliance criterion of the regulatory document according to DSTU $1.7^{[2]}$.

1. Introduction

According to Part 4 of the Article 7 on Law of Ukraine «On metrology and metrological activity» ${ }^{[3]}$ (hereinafter - Law), authority of central bodies of the executive power, other government bodies to authorize enterprises and organizations, their subdivisions and persons, who are subjects of business undertaking activity on provision of certain measurements not connected with conformity assessment of the products, operations and services in the legal metrology sector is regulated by the Law (which regulates requirements to certain kinds of activity).
At the present time, the legal authority of state bodies to authorize enterprises on provision of certain measurements is regulated only in sectors of precious metals circulation, investigation of work environment safety and labor conditions, environmental protection (concerning bodies, which belong to State Ecological Inspection of Ukraine regulation sector).

However, a large quantity of business entities, including those, which operate in the legal metrology regulation sector, request evaluation of the measurement management systems and confirmation of measurement capabilities for their own 
laboratories on a voluntary basis. Such practice is in great demand.

\section{Main Body}

Problems, which can negatively influence on state measurements unity assurance, arise in the process of measurement capabilities evaluation.

Let us define a major of them.

First, a voluntary basis of evaluation and confirmation of measurement capabilities for business entities makes it possible to provide these activities by various organizations, which are not regulated by central bodies of the executive power and are not governmental bodies.

Therefore, various private and public organizations, which referring to Article 24 on Law of Ukraine «On Technical Regulations and Conformity Assessment» ${ }^{[4]}$, determined themselves as bodies for voluntary conformity assessment and offer certain set of services, including issue of conformity certificates and the most alarming is issue of calibration capabilities certificates.

Such organizations provide seminars on the topic, that only by fulfilling the requirements of these bodies for voluntary conformity assessment it is possible to confirm laboratory competence.

By analyzing the mentioned seminars materials, their nonconformity to the effective Laws on metrology was found; this confirms incompetence of such bodies for voluntary conformity assessment in metrological activity issues and other issues, in which they offer certain services including training.

Secondly ${ }^{[5]}$, central bodies of the executive power take illegal actions to authorize providing measurements including the legal metrology sector. This is especially provided in the healthcare sector, where quality management system implementation is controlled particularly in medical laboratories.

The Ministry of Health of Ukraine provides attestation of main organizations of metrological service, which functions include organization and conduct of evaluation of measurement capabilities and confirmation of laboratory competence to authorize providing measurements by the laboratory in the legal metrology sector.

Law does not authorize organizations of metrological service for establishment and attestation. Law of Ukraine «Bases of the legislation of Ukraine on health care» ${ }^{[6]}$ does not determine authorizing of medical laboratories. Taking into account above mentioned facts, such actions by the Ministry of Health of Ukraine can be considered as excess of powers in the legal metrology sector as well as in the attestation sector.

Thirdly, state enterprises, which are regulated by the Ministry of Economy of Ukraine (hereinafter metrological centers), cannot introduce a unified system of evaluation and confirmation of measurement capabilities for business entities.

Problem is that the unified procedure for mentioned works is not currently established. Works on evaluation and confirmation of measurement capabilities for laboratories are provided according to Standards for Organizations in Ukraine (SOU) developed and accepted by metrological centers.

Single effective regulatory act, based on which SOUs were developed, is DSTU ISO 10012:2005 Measurement management systems - Requirements for measurement processes and measuring equipment (ISO 10012:2003, IDT) ${ }^{[1]}$.

Notwithstanding, metrological centers set different requirements for laboratories, provide works using different procedures and issue different documents based on provided works, which differ by form, content and validity term.

Absence of unified terms misinforms enterprises in the process of organizational documents and measurement management system documents development, for unified pricing policy development on mentioned works providing.

Ukrainian system of voluntary measurement assessment (hereinafter - System) was established on a voluntary basis. It is functioning and several metrological centers joined the System, which also has support of business entities. 
This system is imperfect and burdensome for metrological centers. In particular:

- $\quad$ system is intended for separation of laboratories on particular groups and categories, that is not provided by any document, this is inappropriate, as DSTU ISO $10012^{[1]}$ concerns all laboratories;

- system is intended for monitoring laboratories, which received certificates for compliance of the measurement management systems capabilities, that is not provided by any document and metrological centers are not authorized to conduct any supervisory (control) functions;

- system is intended for creation of coordination board, which will be overloaded by unnecessary work and metrological centers will be burdened with additional bureaucratic elements concerning creation and financing the functioning of this board;

- system is burdened with additional bureaucratic elements concerning obtaining the status of system member by metrological centers;

- particular requirements to the laboratory are regulated by the system, that is illegal;

- system provides for development of the set of documents specifying particular requirements and procedures, that is inappropriate. A single document regulating requirements to the laboratories is DSTU ISO $10012^{[1]}$.

The main thing is that System is intended for issuing certificates for compliance of the measurement management subdivisions capabilities with DSTU ISO $10012^{[1]}$.

DSTU ISO $10012^{[1]}$ is identical translation of the relevant international standard. It is developed without considering requirements of the Law.

Moreover, DSTU $10012^{[1]}$ contains particular requirements, which are not implemented on the Ukrainian enterprises and their implementation requires a long period.

Let us consider some of them.

Thus, it is almost impossible to fulfill the following requirements of DSTU $10012^{[1]}$.
According to 7.1.1, metrological compliance provides for calibration and verification of measuring instruments.

Standard is not intended for such terms as conformity assessment of measuring instruments, verification of legal measuring instruments, attestation of the reference materials, measurement for metrological characteristics, evaluation of measuring instruments and equipment, which reproduces normalized external influencing factors and is used in the measurement process.

Generally, customers of evaluation and confirmation of measurement capabilities are laboratories, which provide activities in the legal metrology sector. Such laboratories cannot fulfill the requirements of DSTU ISO $10012^{[1]}$; thus, the requirements of this standard do not meet the requirements of the Law in the part of legal measuring instruments use.

Verification procedures for calibrated measuring instruments fulfilling 7.1.4 are not implemented in the part of making reports on metrological confirmation process and their verification by authorized persons.

According to 7.3.1, measurement uncertainty should be evaluated for each measurement process, covered by the measurement management system.

Such terms as measurement error and, moreover, convergence (the allowable difference between the results of parallel measurements), standard deviation, coefficient of variation, etc. are not determined by the standard.

Currently, most enterprises have no specialists on measurement uncertainty evaluation.

According to 7.3.2, executives of metrological service should provide traceability of all measurement results to measurement standards of SI units.

Moreover, the Law defines traceability as the state of measurements whereby the result can be related to a measurement standard through a documented, unbroken chain of calibrations, each contributing to the measurement uncertainty.

Verification certificate of legal measuring instrument does not provide traceability of measurement results to measurement standards of SI units. 
The following requirements of DSTU ISO $10012^{[1]}$ are not fulfilled.

Subsection 6.1.2. Metrology service executives should ensure personnel training according to requirements, keeping records of provided training, as well as evaluating and recording the effectiveness of training.

Subsection 7.1.2. Methods used for determining or changing the frequency of metrological confirmation should be documented. Frequency should be analyzed and, if it is necessary, corrected for ensuring stable compliance with the determined metrological requirements.

Subsection 8.2.3. (Audit of measurement management system).

Directive. Auditors should not provide inspection of their responsibility area. This directive is not fulfilled by persons, who are subjects of business and enterprises, where independent subdivisions of quality management system, inner auditors, etc. are absent. Even if they are present, they are incompetent in metrological activity.

Possibility to involve in auditing process personnel on contractual basis or third party is not used.

Moreover, as it was stated above, it should be taken into account that metrological centers are not authorized to conduct any supervisory (control) functions. Whereas work of evaluation and confirmation of measurement capabilities is provided on a voluntary basis, then an audit involving personnel on contractual basis or third party should be provided based on voluntary request of the business entity.

\section{Conclusions}

Currently, DSTU $10012^{[1]}$ is not considered as a corresponding normative document by state enterprises regulated by the Ministry of Economy of Ukraine as well as enterprises regulated by other central bodies of the executive power and other enterprises and organizations.

Implementation of DSTU ISO $10012^{[1]}$ requirements is possible only for laboratories operating out of the legal metrology sector. Though, DSTU ISO $10012^{[1]}$ requirements implementation activities are almost not provided by the enterprises.

Taking into account the above stated, issuing the conformity with DSTU ISO $10012^{[1]}$ certificates is impossible, when full conformity is absent.

Voluntary basis of these works may be possible for customers only in decision-making processes concerning evaluation and confirmation of measurement capabilities by an independent body. For metrological centers this kind of activity should be subject to technical regulation, realized by use of SOU, as Law of Ukraine «On Standardization» ${ }^{[7]}$ does not provide for industry standardization (the Ministry level standardization).

The main goal of metrological centers activity instead of issuing conformity of measurement management systems with DSTU ISO $10012^{[1]}$ certificates should be implementation of the standards requirements on the enterprises.

Effective way of the above stated implement is development of the document with the corresponding legal status, which will be the guide for development of SOU by metrological centers for implementation DSTU ISO $10012^{[1]}$ requirements in Ukraine taking into account requirements of the effective Laws on metrology, as well as unification of requirements for providing and formulating results of evaluation and conformation of measurement capabilities for business entities on voluntary basis.

Organization of Systems and creation of Coordination board is not necessary for fulfilling the regulatory and normative documents requirements.

Moreover, revision of the DSTU ISO $10012^{[1]} \mathrm{re}^{-}$ quirements for their combination with requirements of the Law will be appropriate for reissue with conformity criteria MOD. 


\section{References}

1. DSTU ISO 10012:2005 Measurement management systems - Requirements for measurement processes and measuring equipment (ISO 10012:2003, IDT) [ДСТУ ISO 10012:2005 Системи керування вимірюванням. Вимоги до процесів вимірювання та вимірювального обладнання (ISO 10012:2003, IDT)]. [In Ukrainian]

2. DSTU 1.7:2015 (ISO/IEC Guide 21-1:2005, NEQ; ISO/IEC Guide 21-2:2005, NEQ) National standardization. Rules and requirements of adopting of international and regional normative documents [ДСТУ 1.7:2015 (ISO/IEC Guide 211:2005, NEQ; ISO/IEC Guide 21-2:2005, NEQ) Національна стандартизація. Правила та методи прийняття міжнародних і регіональних нормативних документів]. [In Ukrainian]

3. Law of Ukraine «On metrology and Metrological Activity» [3aкон України «Про метрологію та метрологічну діяльність»] [In Ukrainian]
4. Law of Ukraine «On standards, technical regulations and conformity assessment procedures» [Закон України «Про технічні регламенти та оцінку відповідності»]. [In Ukrainian]

5. Glebov A. B., Chyzhyk I. V., Parkhomenko N. M., Dengub O. V. 2020 Features of the functioning of the national metrological system in the health sector [Особливості функціонування національної метрологічної системи у сфері охорони здоров'я]. Metrology and Instruments. 1, pp. 59-65. [In Ukrainian]

6. Law of Ukraine «Bases of the legislation of Ukraine on health care» [Закон України «Основи законодавства України про охорону здоров'я»] [In Ukrainian]

7. Law of Ukraine «On Standardization» [Закон України «Про стандартизацію»]. [In Ukrainian] 